\title{
The effects of blood flow restriction exercise on vascular function in the elderly: A systematic review
}

\author{
Samuel Amorim ${ }^{1}$, Alexandra P Gaspar ${ }^{1}$, Hans Degens ${ }^{2,3,4}$ and Luciana DNJ de Matos ${ }^{1 *}$ \\ ${ }^{1}$ Hospital Israelita Albert Einstein, São Paulo, Brazil \\ ${ }^{2}$ Research Centre for Musculoskeletal Science \& Sports Medicine, Manchester Metropolitan University, England \\ ${ }^{3}$ Lithuanian Sports University, Kaunas, Lithuania \\ ${ }^{4}$ University of Medicine and Pharmacy of Targu Mures, Rumania
}

\begin{abstract}
Background: Blood flow restriction (BFR) exercise has been used to induce skeletal muscle and aerobic adaptations that are similar to those induced by high intensity training, but with less time and lower intensities. The lower time demand and exercise intensity appear advantageous, especially for older people but there may be risks associated with a potential impairment of vascular function after BFR trainings. Therefore, the purpose of this systematic review was to evaluate the effects of aerobic and resistance exercise with BFR on vascular function in the elderly.
\end{abstract}

Methods: PubMed, Embase, Scopus, Lilacs, Web of science, Pedro, Google Scholar and the Cochrane library were searched for articles published until January 2019. This review included randomized and non-randomized controlled trials of BFR exercise for $\geq 4$ weeks in older humans.

Results: In the first step, 133 articles were identified, of which 22 articles met the inclusion criteria. Sixteen studies were excluded because of the short training period $(<4$ weeks) or the average age of participants ( $<60$ years). Six articles were included in this review ( $\mathrm{n}=146$ individuals, mean age $=69$ years old, $71,46 \%$ women and $28,54 \%$ men). BFR combined with aerobic exercise $(n=2)$ enhanced arterial and venous compliance in healthy elders and resistance exercises $(n=4)$ demonstrated no significant effects on vascular function in healthy elders compared to exercise without BFR.

Conclusion: These results suggest that the addition of BFR to exercise does even improve vascular function in healthy elderly people. This is a first indication that superimposing BFR is safe also in sedentary elders. However, future research, especially in sedentary elders, is necessary to assess the safety of this method.

\section{Introduction}

Blood flow restriction (BFR) exercise is a well-established method to induce muscle hypertrophy in different age groups [1,2], athletes [3], healthy elderly [4-6] and patients with chronic diseases [7-12]. One of the main advantages cited is that this method elicits similar physiological adaptations to that seen in response to high intensity aerobic [8-10] or resistance training $[15,16]$, but in less time (4-6 week) and with lower exercise intensities (20\% to $50 \%$ of one maximum repetition) [17]. This demand for fewer exercise sessions and lower exercise intensities may be particularly advantageous for frail people, such as inactive elders [18], and persons with injuries or in post-surgery [19].

There is, however, some evidence that BFR may have a negative effects on hemodynamic system, as higher blood systolic and diastolic responses has been observed in elders and patients with hypertension [20]. Part of this may be attributable to accumulation of metabolites (lactate, protons, $\mathrm{K}^{+}$) by $\mathrm{BFR}$ and consequently, metaboreflex stimulation, that results in increased sympathetic activity and, elevated blood pressure and heart rate [20]. An impaired vascular function after BFR may be particularly of concern in elderly with comorbidities, and while there may thus be muscular benefits of BFR in this population, they may not outweigh the risks associated with a reduced vascular function. Therefore, here we review the literature on the effects of BFR combined with aerobic and resistance exercises on the vascular function in the elderly.

\section{Methods}

\section{Search strategy}

The information in this review was obtained through a search of The National Library of Medicine (PubMed), Embase, Scopus, Lilacs, Web of science, Pedro, Google Scholar and the Cochrane library, considering the period until January 2019. The chart (PRISMA (Supplementary chart)) describes the selection process of the studies reviewed (Figure 1). A comprehensive search in databases and in additional sources such as theses revealed a total of 133 articles. Out of those, 111 publications were excluded based on the title and abstract information. The remaining 22 articles were selected for full-text reading; of these, 6 fulfilled the eligibility criteria, including methodological quality of the studies and the age of the participants. Subsequently, a systematic assessment of changes induced by BFR exercises in the vascular system of older individuals was performed. All selected articles were assessed independently by two reviewers

${ }^{\star}$ Correspondence to: Luciana Diniz Nagem Janot de Matos, Hospital Israelita Albert Einstein, Avenida Albert Einstein 627/701, Jardim Leonor - CEP: 05652-900 - São Paulo, SP - Brazil, Tel. +5511 2151-1444, E-mail: lucianajanot@einstein.br

Key words: KAATSU, blood flow restriction training, vascular function, elderly

Received: February 15, 2019; Accepted: February 28, 2019; Published: March 04,2019 


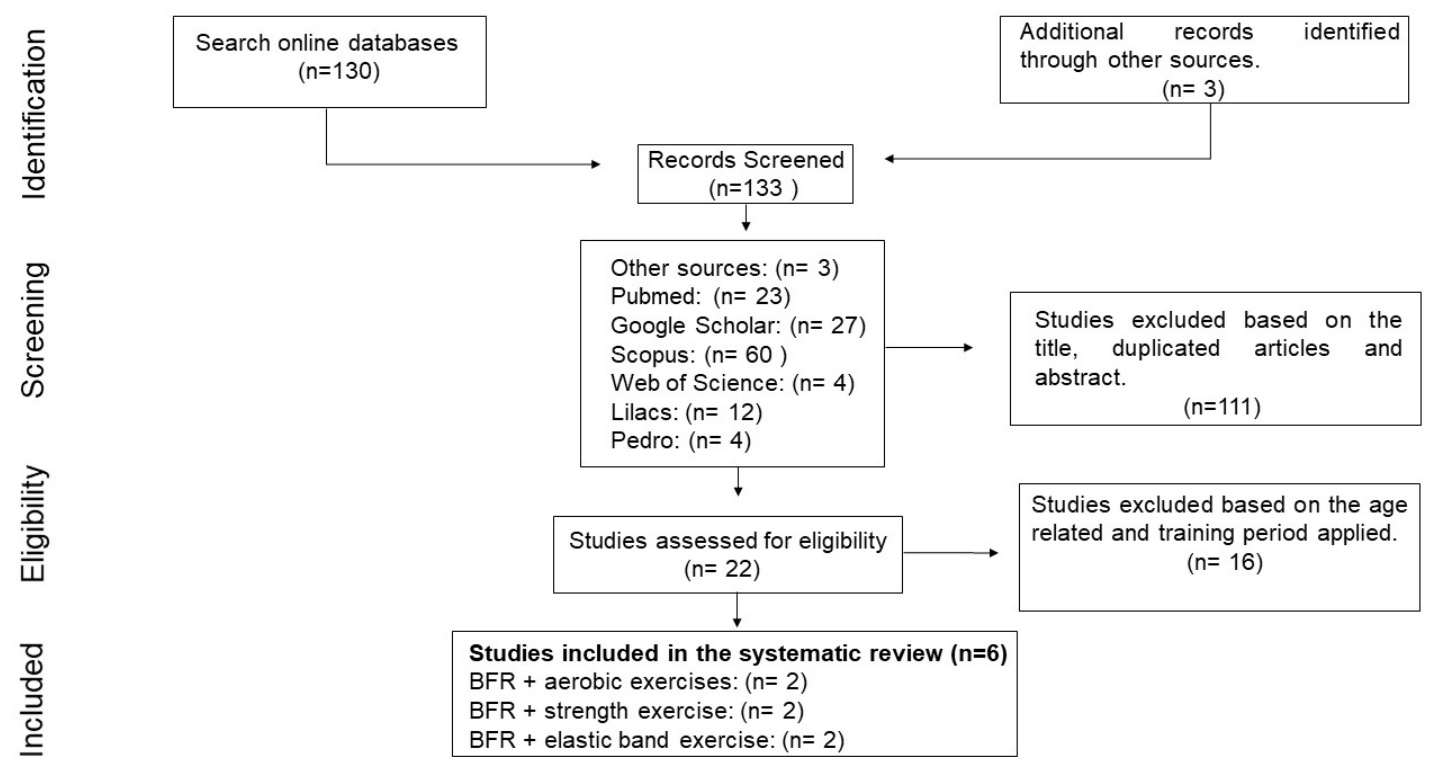

Figure 1: The flow diagram indicates the study selection

and disagreements were solved through discussion with the help of a third reviewer (3). In addition, both titles and abstracts were read in order to perform the screening. Then the studies which included relevant information were retrieved and read in full. The references section of the articles was examined to identify any potentially pertinent studies that had not been previously selected during the online search.

\section{Definition of terms}

The major English keywords and terms used to search were: ('kaatsu' or 'blood flow restriction training' or 'blood flow restriction exercise' or 'vascular occlusion training') AND ('vascular function' or 'endothelial function') AND ('arterial compliance or arterial stiffness') AND ('aging' or 'elderly' or 'ageing').

\section{Inclusion and exclusion criteria}

The inclusion criteria in this systematic review were organized according to the principle of PICOS (P: participants; I: intervention; $\mathrm{C}$ : comparison; O: outcomes; S: study designs). The details of inclusion criteria are explained as follows: P: humans with mean aged $>60$ years; (2) I: the experimental group performed aerobic or resistance exercises with BFR and a specific description of exercise protocol was reported; (3) $\mathrm{C}$; aerobic and resistance exercises (strength and elastic bands exercises); (4) $\mathrm{O}$; the outcomes were vascular responses of training during $\geq 4$ weeks; (5) S: randomized controlled trials (RCTs) and non-randomized controlled trials (NRCTs); and full-text articles with English language only. Therefore, conference abstracts, letters to the editor, theses, unpublished data, case report, and review articles were excluded.

\section{Outcome measures}

The outcome measures were focused on endothelial function, arterial stiffness, venous and arterial compliance. Some methods were used to evaluate the effects of BFR training on vascular function in the selected studies: cardio ankle vascular index (CAVI), ankle brachial index (ABI), flow mediated dilatation (FMD), von Willebrand factor (vWF) and reactive hyperemia index (RHI) (Table 1).

\section{Quality assessment}

According to the quality assessment of all eligible articles was evaluated using a modified version of Downs and Black checklist for assessing RCTs and NRCTs [21]. The 27 questions in checklist are related to reporting, external validity, internal validity and statistical power. In addition, the highest score for the checklist was 17 . Hence, the studies were classified as excellent (26-28), good (20-25), fair (15$19)$, and poor $(\leq 14)$.

\section{Results}

The summary of the results is presented in Table 2. There were 146 participants in the 6 selected studies, with an average age of 69 years. BFR was associated with aerobic exercise in two studies and resistance exercises in four (2 elastic bands and 2 strength exercises). The period of training ranged from four to twelve weeks.

\section{Methodological quality assessment}

The quality assessment of the studies is reported in Table 3. The main findings were that the external validity of studies included were poor and three studies were NRCTs. Furthermore, the studies were classified as poor and fair methodological quality.

\section{Aerobic exercise combined with blood flow restriction}

The studies that combined walking exercise with BFR showed positive effects on venous and arterial compliance in the elderly people with low level of physical activity [14,22].

Lida et al. [23] studied the effect of slow walking with BFR (20 minutes treadmill walking - $67 \mathrm{~m} \mathrm{~min}^{-1}$ ) on venous compliance, measured by venous occlusion plethysmography, in untrained 59 to 78-year-old women $(\mathrm{n}=9)$ versus a non-exercising control group $(\mathrm{n}=$ 7). They demonstrated a significant increase in leg venous compliance and maximal venous outflow in the intervention group only.

Ozaki et al. [22] examined the effects of walk training $(20 \mathrm{~min}$ treadmill walking - exercise intensity: $45 \%$ of heart rate reserve with (n $=13)$ or without $(\mathrm{n}=10)$ BFR on carotid artery compliance and muscle size in elderly. They found that carotid compliance improved in both 
Table 1. The overview of outcome measures in the studies included in this systematic review

\begin{tabular}{|c|c|c|c|}
\hline Study & Outcome & Mean $(95 \%$ CI or SD) & \\
\hline & BFR-R group & Pre-exercise & Post-exercise \\
\hline \multirow[t]{5}{*}{ Shimizu, et al. [27] } & Reactive hyperemia index & $1.8 \pm 0.2$ & $2.1 \pm 0.3 * *$ \\
\hline & Von Willebrand factor & $175.7 \pm 20.3$ & $156.3 \pm 38.1^{*}$ \\
\hline & Non BFR group & & \\
\hline & Reactive hyperemia index & NR & NR \\
\hline & Von Willebrand factor & NR & NR \\
\hline \multirow[t]{8}{*}{ Yasuda, et al. [26] } & BFR group & & \\
\hline & CAVI $(\mathrm{m} / \mathrm{s})$ & $9.1(1.4)$ & $9.0(1.5)$ \\
\hline & ABI (unit) & $1.13(0.07)$ & $1.15(0.06)$ \\
\hline & FMD (\%) & $2.8(2.0)$ & $4.4(2.5)^{*}$ \\
\hline & Control group & & \\
\hline & CAVI $(\mathrm{m} / \mathrm{s})$ & $8.7(0.8)$ & $8.5(1.1)$ \\
\hline & ABI (unit) & $1.13(0.10)$ & $1.13(0.09)$ \\
\hline & FMD (\%) & $4.4(1.8)$ & $3.9(2.5)$ \\
\hline \multirow[t]{9}{*}{ Yasuda, et al. [47] } & BFR-Tr group & & \\
\hline & CAVI $(\mathrm{m} / \mathrm{s})$ & $8.14(0.9)$ & $8.5(0.8)$ \\
\hline & ABI (unit) & $1.14(0.06)$ & $1.15(0.04)$ \\
\hline & MH-Tr & & \\
\hline & CAVI $(\mathrm{m} / \mathrm{s})$ & $8.4(0.9)$ & $8.5(0.8)$ \\
\hline & ABI (unit) & $1.11(0.05)$ & $1.11(0.08)$ \\
\hline & Control group & & \\
\hline & CAVI $(\mathrm{m} / \mathrm{s})$ & $8.3(0.8)$ & $8.4(0.7)$ \\
\hline & ABI (unit) & $1.11(0.06)$ & $1.12(0.05)$ \\
\hline \multirow[t]{8}{*}{ Yasuda, et al. [26] } & BFR group & & \\
\hline & CAVI $(\mathrm{m} / \mathrm{s})$ & $8.9(1.2)$ & $9.2(1.1)$ \\
\hline & ABI (unit) & $1.17(0.07)$ & $1.14(0.09)$ \\
\hline & FMD (\%) & $3.6(2.1)$ & $4.3(3.1)$ \\
\hline & Control group & & \\
\hline & CAVI (m/s) & $8.5(0.7)$ & $8.2(0.8)$ \\
\hline & ABI (unit) & $1.10(0.10)$ & $1.10(0.09)$ \\
\hline & FMD (\%) & $4.3(1.6)$ & $3.5(2.0)$ \\
\hline \multirow[t]{4}{*}{ Lida et al. [48] } & BFR walking group & & \\
\hline & 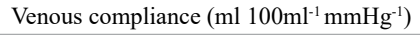 & $0.0518 \pm 0.0084$ & $0.0518 \pm 0.0084^{*}$ \\
\hline & Control group & & \\
\hline & 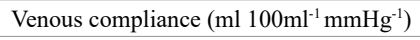 & $0.0686 \pm 0.0160$ & $0.0637 \pm 0.0067$ \\
\hline \multirow[t]{4}{*}{ Ozaki et al. [49] } & BFR walking group & & \\
\hline & Arterial compliance & $0.984(0.012)$ & $0.118(0.016)^{*}$ \\
\hline & Control group & & \\
\hline & Arterial compliance & $0.079(0.009)$ & $0.114(0.010)^{*}$ \\
\hline
\end{tabular}

BFR: Blood Flow Restriction; BFR-R: Blood Flow Restriction Training; Non BFR- Low Intensity Resistance Training, BFR-Tr: Low Intensity Elastic Band BFR Training; MH-Tr: Middle to High Intensity Elastic Band Resistance Training; CAVI: Cardio Ankle Vascular Index; ABI: Ankle Brachial Index; FMD: Flow Mediated Dilatation, NR: Not Reported

**Significant difference from Non-BFR group

groups $($ BFR group $=50 \%$ and control group $=59 \%$ ), but only walking combined with BFR improved MRI-measured thigh muscle cross-area (3\%) and strength (15\%).

\section{Resistance exercises combined with blood flow restriction}

Yasuda et al. [24-26] demonstrated in three studies that elastic band and strength exercises combined with BFR increased muscle cross-sectional area and muscle strength, without negative effects on hemodynamic parameters (heart rate and blood pressure), coagulation factors, or alterations in arterial stiffness and endothelial function in older people assessed by ABI, CAVI and FMD, respectively.

Shimizu et al. [27] reported that four weeks of BFR combined with resistance exercises enhanced vascular endothelial function and peripheral blood circulation above that induced by resistance exercise training without BFR in healthy elderly people. This study evaluated endothelial function by reactive hyperemia index (RHI), endothelial cell damage by von Willebrand factor (vWF), and peripheral circulation by transcutaneous oxygen pressure in the foot (Foot-tc-PO2). The authors showed that there was an increase in RHI and decrease in vWF after 4-weeks of BRF resistance training. In addition, the BFR demonstrated a significant indicating enhanced peripheral circulation compared with the group without BFR.

These studies thus suggest that BFR combined with resistance exercise does not impair vascular function and may in fact even improve vascular function beyond that induced by resistance exercise alone, and thus be safely applied in older healthy people.

\section{Discussion}

The data of BFR exercise in the older population so far suggests that BFR superimposed on both aerobic and resistance exercise not only enhances muscle hypertrophy, but also has no significant negative effect, or even improves vascular function. This is a potentially 
Table 2. The effects of blood flow restriction exercise on vascular function in the elderly

\begin{tabular}{|c|c|c|c|c|c|c|c|c|c|c|c|c|}
\hline $\begin{array}{c}\text { Author } \\
\text { (year) }\end{array}$ & Subjects & $\begin{array}{c}\text { Trial } \\
\text { design }\end{array}$ & $\begin{array}{l}\text { Age } \\
\text { (yrs) }\end{array}$ & $\begin{array}{l}\text { Type of } \\
\text { Exercise }\end{array}$ & $\begin{array}{l}\text { Exercise } \\
\text { intensity }\end{array}$ & $\begin{array}{l}\text { Occlusion } \\
\text { time (min) }\end{array}$ & \begin{tabular}{|c|}
$\begin{array}{c}\text { Exercise prescription } \\
\text { (reps, sets, time and } \\
\text { rest periods) }\end{array}$ \\
\end{tabular} & $\begin{array}{l}\text { Period of } \\
\text { Training }\end{array}$ & $\begin{array}{c}\text { Cuff } \\
\text { width } \\
(\mathrm{cm})\end{array}$ & $\begin{array}{l}\text { Applied Cuff } \\
\text { pressure } \\
\text { (mmHg) }\end{array}$ & $\begin{array}{l}\text { Inflator } \\
\text { Devices }\end{array}$ & Main results \\
\hline $\begin{array}{l}\text { Shimizu, } \\
\text { et al. [27] }\end{array}$ & $\begin{array}{c}33 \text { men } \\
7 \text { women }\end{array}$ & $\mathrm{R}$ & 71 & $\begin{array}{l}\text { KE, LP, R, } \\
\text { BP }\end{array}$ & $20 \% 1 \mathrm{RM}$ & 15 & $\begin{array}{c}3 \text { sets of } 20 \text { reps for } \\
\text { each exercise with } \\
30 \text { s between sets } 60 \mathrm{~s} \\
\text { between exercises. }\end{array}$ & $\begin{array}{c}3 \text { days a week } \\
4 \text { weeks }\end{array}$ & $\begin{array}{c}7(\mathbf{U B}) \\
10(\mathbf{L B})\end{array}$ & NR & $\begin{array}{c}\text { Tourniquet } \\
9000\end{array}$ & VEGF $(+)$ \\
\hline $\begin{array}{l}\text { Yasuda, et } \\
\text { al. [26] }\end{array}$ & $\begin{array}{c}5 \text { men } \\
14 \text { women }\end{array}$ & $\mathrm{R}$ & $61-84$ & KE, LP & $\begin{array}{c}20 \%-30 \% \\
1 \mathrm{RM}\end{array}$ & 11 & $\begin{array}{c}1 \text { set of } 30 \text { reps }+1 \\
\text { set of } 20 \text { reps }+1 \text { set } \\
\text { of } 15 \text { reps }+1 \text { set of } \\
10 \text { reps } \\
\text { with rest periods } \\
\text { around } 30 \text { s between } \\
\text { sets and } 90 \text { s between } \\
\text { exercises. }\end{array}$ & $\begin{array}{c}2 \text { days a week } \\
12 \text { weeks }\end{array}$ & 5 & $120-270$ & $\begin{array}{l}\text { KAATSU } \\
\text { Master }\end{array}$ & $\begin{array}{l}\text { FMD }(\sim), \text { CAVI } \\
\quad(\sim), \text { ABI }(\sim)\end{array}$ \\
\hline $\begin{array}{l}\text { Yasuda, et } \\
\text { al. [47] }\end{array}$ & 30 women & $\mathrm{R}$ & $61-86$ & KE, S & $\begin{array}{l}\text { EB: black } \\
\text { and } \\
\text { gold }\end{array}$ & $10-11$ & $\begin{array}{l}1 \text { set of } 30 \text { reps }+3 \\
\text { sets of } 15 \text { reps with } \\
\text { rest periods } \\
\text { of } 30 \text { s between sets } \\
\text { and } 90 \text { s between } \\
\text { exercises. }\end{array}$ & $\begin{array}{c}2 \text { days a week } \\
12 \text { weeks }\end{array}$ & 5 & $160-200$ & $\begin{array}{l}\text { KAATSU } \\
\text { Master }\end{array}$ & $\begin{array}{c}\text { FMD }(\sim), \\
\text { CAVI }(\sim), \text { ABI } \\
(\sim)\end{array}$ \\
\hline $\begin{array}{l}\text { Yasuda, et } \\
\text { al. [25] }\end{array}$ & $\begin{array}{c}3 \text { men } \\
14 \text { women }\end{array}$ & NR & $61-85$ & $\mathrm{BF}, \mathrm{TP}$ & EB: Yellow & 9.5 & $\begin{array}{l}1 \text { set of } 30 \text { reps }+1 \text { set } \\
\text { of } 20+1 \text { set of } 15,10 \\
\text { reps with rest periods } \\
\text { of } 30 \text { s between sets } \\
\text { and } 90 \text { s between } \\
\text { exercises. }\end{array}$ & $\begin{array}{c}2 \text { days a week } \\
12 \text { weeks }\end{array}$ & 3 & $180-270$ & $\begin{array}{l}\text { KAATSU } \\
\text { Master }\end{array}$ & $\begin{array}{l}\text { FMD }(\sim), \text { CAVI } \\
\quad(\sim), \text { ABI }(\sim)\end{array}$ \\
\hline $\begin{array}{l}\text { Lida et al. } \\
\text { [48] }\end{array}$ & 16 women & NR & $59-78$ & Walking & $67 \mathrm{~m} / \mathrm{min}$ & 23 & 20 minutes & $\begin{array}{c}5 \text { days a week } \\
6 \text { weeks }\end{array}$ & NR & $180-200$ & $\begin{array}{l}\text { KAATSU } \\
\text { Master }\end{array}$ & $\begin{array}{c}\mathrm{DBP}(+), \mathrm{LVC} \\
(+)\end{array}$ \\
\hline $\begin{array}{l}\text { Ozaki et } \\
\text { al. [49] }\end{array}$ & $\begin{array}{c}3 \text { men } \\
10 \text { women }\end{array}$ & NR & $57-76$ & Walking & $45 \%$ HRR & 20 & 20 minutes & $\begin{array}{c}4 \text { days a week } \\
10 \text { weeks }\end{array}$ & 5 & $140-200$ & $\begin{array}{l}\text { KAATSU } \\
\text { Master }\end{array}$ & $\mathrm{AC}(+)$ \\
\hline
\end{tabular}

Abbreviations: R: Randomized; NR: Not Randomized; SBP: Systolic Blood Pressure; DBP: Diastolic Blood Pressure; HRR: Heart Rate Reserve; BW: Body Weight; S: Squat; BF: Biceps Flexion; TP: Triceps Press; BP: Bench Press; R: Rowing; KE: Knee Extension; KF: Knee Flexion; LP: Leg Press; EB: Elastic Bands; VF: Vascular Function; CAVI: Cardio Ankle Vascular Index, PWV: Pulse Wave Velocity; ABI: Ankle-Brachial Blood Pressure Index; AC: Arterial Compliance; RM: Repetition Maximum; FMD: Flow Mediate Dilation; SV: Stroke Volume; VEGF: Vascular Endothelial Growth Factor; UB: Upper Body; LB: Lower Body; LVC: Limb Venous Compliance; +: Positive Effect, -: Negative Effect, : No Effect; NR: Not Reported

Table 3. Quality assessment

\begin{tabular}{|c|c|c|c|c|c|c|c|}
\hline Study & Communication & External Validity & $\begin{array}{c}\text { Internal Validity } \\
\text { (bias) }\end{array}$ & $\begin{array}{l}\text { Internal Validity } \\
\text { confounding } \\
\text { (selection bias) }\end{array}$ & Power & Total score & Rating \\
\hline Shimizu, et al. [27] & 7 & 1 & 4 & 4 & 1 & 17 & Fair \\
\hline Yasuda, et al. [26] & 7 & 1 & 4 & 3 & 1 & 16 & Fair \\
\hline Yasuda, et al. [47] & 7 & 1 & 5 & 3 & 1 & 17 & Fair \\
\hline Yasuda, et al. [25] & 7 & 1 & 4 & 4 & 1 & 17 & Fair \\
\hline Lida et al. [48] & 5 & 1 & 3 & 3 & 1 & 13 & Poor \\
\hline Ozaki et al. [49] & 7 & 1 & 3 & 1 & 1 & 13 & Poor \\
\hline
\end{tabular}

significant observation as in particular older frail people may benefit from an increased skeletal muscle mass, but often find high intensity resistance exercises may too demanding and with BFR it is possible that the intensity and frequency of exercise can be reduced while eliciting the same benefits [28].

Ageing is associated with loss of skeletal muscle mass and decrements in cardiovascular function that may hamper rehabilitation in the older person.

Although training with BFR appears to be as an interesting option, it is important to keep in mind that aging is accompanied by vascular modifications, such as endothelial dysfunction, increased arterial stiffness, diminished responsiveness of local vascular control mechanisms and reduction in cardiac pump effectiveness [29]. This is an important consideration as one study in older people and hypertensive individuals reported BFR-induced deterioration of hemodynamic function [20].

Dysfunction of the vascular endothelium might be caused by oxidative stress, reduction of nitric oxide synthesis and consequently attenuated arteriolar dilation [30].
For this review, we found only six studies that evaluated the impact of BFR superimposed on exercise on vascular function in healthy and sedentary elders. None of these studies reported any undesirable side effects on vascular function, irrespective of the training type combined BRF.

It is important to highlight that most of the studies were conducted with the KAATSU master device (5 studies) and only one with an adapted BFR technique (Tourniquet 9000). Importantly, there are no studies with other adapted blood flow restriction methods associated with training that evaluated their safety in relation to the vascular function in the elderly.

The studies with aerobic exercise enhanced limb venous and carotid arterial compliance in sedentary elders [14,22]. However, in Ozaki's study, the increase in carotid arterial compliance was similar in the walking with and without BFR groups (without - pre: $0.079 \mathrm{~mm}^{2} /$ mmHg, post: $0.114 \mathrm{~mm}^{2} / \mathrm{mmHg} P<0.01$ and with BFR pre: $0.084 \mathrm{~mm}^{2} /$ $\mathrm{mmHg}$, post: $\left.0.118 \mathrm{~mm}^{2} / \mathrm{mmHg}-P<0.01\right)(29)$. These results suggest that walking exercise was, by itself, responsible for these responses and 
the KAATSU training did not have any additional effect. Even so, BFR did not attenuate the benefits of walking.

It has been reported that older people who regularly perform aerobic exercise, such as master athletes have better vascular endothelial function and better compliance large elastic artery [30,31]. On the other hand, high intensity resistance exercises can increase arterial stiffness and should be avoided in older people [32].

The studies of BFR with elastic bands did not show any significant modification of the vascular function in either the upper or lower body. Similarly, low intensity strength exercises with BFR induced no changes in arterial stiffness [26], but rather enhancements in the endothelial function and peripheral circulation were found [27]. These positive results could be related to the training frequency. While in the Yasuda et al. study [25] the frequency of training was twice a week, Shimizu et al. [27] did the exercise three times a week. It is known that training variables such as occlusion pressure, cuff size, exercise session time, training volume, rest time and training intensity influence hemodynamic responses, and also have an effect on vascular function [3,17,33-35]. However, this bias is minimized as in both studies training with BFR was compared to an identical training without BFR and hence any differences can be ascribed to BFR.

It is generally thought that, the additional benefits of BFR superimposed on exercise are attributable to the hypoxic stress, that would cause an augmented secretion of factors such as lactate (Lac), norepinephrine (NE), vascular endothelial growth factor (VEGF) and growth hormone (GH) $[16,36]$. Indeed, it has been demonstrated that BRF stimulates VEGF release from both vascular endothelium and skeletal muscle cells [37]. VEGF bound to its receptors on the endothelial cell membrane in turn increases eNOS expression, increasing local NO production [38] and thereby stimulates vasodilation and endothelial cell proliferation. Thus, increased VEGF in response to the reduction of muscle blood flow during an exercise session may well induce proliferation and migration of endothelial cells and accelerate angiogenesis in the skeletal muscles [39,40] (Figure 2).

In parallel, it has been demonstrated that the serum concentration of $\mathrm{GH}$ after a single bout of low intensity resistance training increases more after resistance exercise with BFR compared to that induced by resistance exercise without BRF [22]. Growth hormone has, like VEGF, been shown to upregulate eNOS expression in endothelial cells and thereby improve vascular endothelial function $[41,42]$, and may also play a role in the development of muscle hypertrophy $[27,39]$.
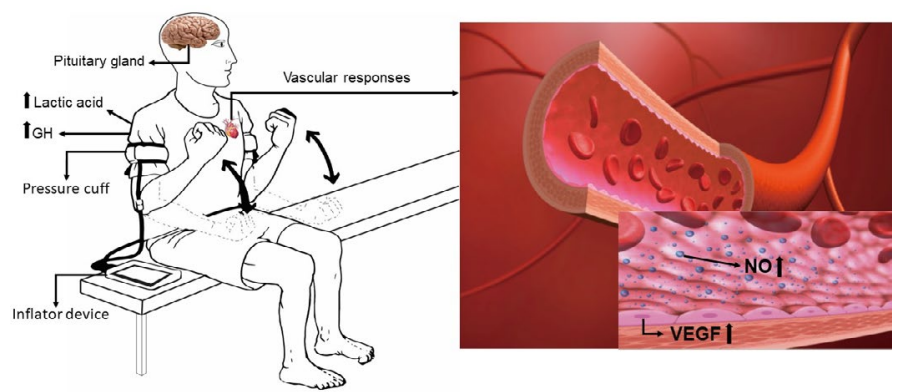

Figure 2. Illustration demonstrating the influence of BFR method in vascular responses and the physiological effects

Legends: GH - Growth hormone, NO - Nitric Oxide, VEGF - Vascular endothelial growth factors.
Part of this positive response may not only be due to hypoxia, but also to a lesser endothelial cell damage as reflected by increased RHI and reduction of Von Willebrand factor (vWF) [43]. VWF is an important glycoprotein, which has function in homeostasis and thrombus formation [43]. During ageing, the levels of vWF increase significantly, and is associated with an increased risks of coronary heart disease and thrombotic disorders $[45,46]$. Therefore, the BFR induced reduction vWF, may improve the coagulation system, circulation and thereby the risk of cardiovascular complications.

\section{Limitations}

Although the studies published so far favor the use of BFR with aerobic and resistance training, they are few and many from the same research group. In addition, the types of exercise and methods of analysis of vascular function were heterogeneous hindering detailed statistical analysis. Hence, the methodological quality of studies was considered poor and fair, especially external validity that contains questions regarding the study population. For the wide use of this technique and its expansion for the elderly population with comorbidities, future research is necessary, mainly in relation to the safety of the method and to further evaluate whether indeed the superimposing BFR enhances the gains of conventional aerobic or resistance exercise.

\section{Conclusion and future directions}

The studies with BFR combined with aerobic and resistance exercises in healthy elderly people showed positive or neutral results with respect to vascular function. However, the number of studies focused on both methods in elders are still limited and more studies to evaluate the safety of these types of training should be conducted, especially in sedentary and frail elderly people. Nevertheless, the first indications are that training and therapy with BRF may be applied safely and with enhanced benefits of muscle hypertrophy and vascular function in rehabilitation of the older person.

\section{Conflicts of interest}

The authors declare that there is no conflict of interest regarding the publication of this paper.

\section{References}

1. Pearson SJ, Hussain SR (2015) A Review on the Mechanisms of Blood-Flow Restriction Resistance Training-Induced Muscle Hypertrophy. Sport Med 45: 187200. [Crossref]

2. Hughes L, Paton B, Rosenblatt B, Gissane C, Patterson SD (2017) Blood flow restriction training in clinical musculoskeletal rehabilitation: a systematic review and meta-analysis. Br J Sports Med 51: 1003-1011. [Crossref]

3. Scott BR, Loenneke JP, Slattery KM, Dascombe BJ (2015) Exercise with Blood Flow Restriction: An Updated Evidence-Based Approach for Enhanced Muscular Development. Sports Med 45: 313-235. [Crossref]

4. Ferreira MLV, Sardeli AV, Souza GV De, Bonganha V, Santos LDC, et al. (2016) Cardiac autonomic and haemodynamic recovery after a single session of aerobic exercise with and without blood flow restriction in older adults. J Sports Sci 35: 24122420. [Crossref]

5. Fry CS, Glynn EL, Drummond MJ, Timmerman KL, Fujita S, et al. (2010) Blood flow restriction exercise stimulates mTORC1 signaling and muscle protein synthesis in older men. J Appl Physiol 108: 1199-209. [Crossref]

6. Libardi CA, Chacon-Mikahil MP, Cavaglieri CR, Tricoli V, Roschel H, et al. (2015) Effect of concurrent training with blood flow restriction in the elderly. Int $J$ Sports Med 36: 395-399. [Crossref]

7. Pinto RR, Karabulut M, Poton R, Polito MD (2016) Acute resistance exercise with blood flow restriction in elderly hypertensive women: Haemodynamic, rating of perceived exertion and blood lactate. Clin Physiol Funct Imaging 1-8. [Crossref] 
8. Cook SB, LaRoche DP, Villa MR, Barile H, Manini TM (2017) Blood flow restricted resistance training in older adults at risk of mobility limitations. Exp Gerontol 99: 13845. [Crossref]

9. Mattar MA, Gualano B, Perandini LA, Shinjo SK, Lima FR, et al. (2014) Safety and possible effects of low-intensity resistance training associated with partial blood flow restriction in polymyositis and dermatomyositis. Arthritis Res Ther 16: 473. [Crossref]

10. Noto T, Hashimoto G, Takagi T, Leigh JS Jr, Natelson BH (2018) Muscle Metabolism With Blood Flow Restriction in Chronic Fatigue Syndrome. J Foot Ankle Surg 18: 2595-601. [Crossref]

11. Satoh I (2011) Kaatsu Training: Application to Metabolic Syndrome. Int J KAATSU Train Res 7: 7-12.

12. Madarame H, Kurano M, Fukumura K, Fukuda T, Nakajima T (2013) Haemostatic and inflammatory responses to blood flow-restricted exercise in patients with ischaemic heart disease: A pilot study. Clin Physiol Funct Imaging 33: 11-17. [Crossref]

13. Clarkson MJ, Conway L, Warmington SA (2017) Blood flow restriction walking and physical function in older adults: A randomized control trial. J Sci Med Sport 20: 10411046 [Crossref]

14. Iida H, Nakajima T, Kurano M, Yasuda T, Sakamaki M, et al. (2011) Effects of walking with blood flow restriction on limb venous compliance in elderly subjects. Clin Physiol Funct Imaging 31: 472-476. [Crossref]

15. Takarada Y, Takazawa H, Sato Y, Takebayashi S, Tanaka Y, et al. (2000) Effects of resistance exercise combined with moderate vascular occlusion on muscular function in humans. J Appl Physiol 88:2097-106. [Crossref]

16. Takarada Y, Nakamura Y, Aruga S, Onda T, Miyazaki S, Ishii N (2000) Rapid increase in plasma growth hormone after low-intensity resistance exercise with vascular occlusion Rapid increase in plasma growth hormone after low-intensity resistance exercise with vascular occlusion. $J$ Appl Physiol 88: 61-65. [Crossref]

17. Fahs C a, Loenneke JP, Rossow LM (2012) Methodological considerations for blood flow restricted resistance exercise. J Trainology 1: 14-22.

18. Centner C, Wiegel P, Gollhofer A, Konig D (2018) Effects of Blood Flow Restriction Training on Muscular Strength and Hypertrophy in Older Individuals?: A Systematic Review and Meta - Analysis. Sports Med 49: 95-108. [Crossref]

19. Day B (2018) When and Where Can It Accelerate Rehabilitation. Arthrosc J Arthrosc Relat Surg 34: 2511-2513.

20. Domingos E, Polito MD (2018) Blood pressure response between resistance exercise with and without blood $\mathrm{fl}$ ow restriction?: A systematic review and meta-analysis. Life Sci 209: 122-131.

21. Answers P (2016) Appendix 12 (as supplied by the authors): Modified Downs and Black checklist for the assessment of the methodological quality of both randomized and non-randomized studies 1. 12: 11-13.

22. Ozaki H, Miyachi M, Nakajima T, Abe T (2011) Effects of 10 weeks walk training with leg blood flow reduction on carotid arterial compliance and muscle size in the elderly adults. Angiology 62: 81-86. [Crossref]

23. Iida H1, Nakajima T, Kurano M, Yasuda T, Sakamaki M, et al. (2011) Effects of walking with blood flow restriction on limb venous compliance in elderly subjects. Clin Physiol Funct Imaging 31: 472-476. [Crossref]

24. Yasuda T, Fukumura K, Uchida Y, Koshi H, Iida H, et al. (2015) Effects of low-load, elastic band resistance training combined with blood flow restriction on muscle size and arterial stiffness in older adults. J Gerontol A Biol Sci Med Sci 70: 950-958. [Crossref]

25. Yasuda T, Fukumura K, Tomaru T, Nakajima T (2014) Thigh muscle size and vascular function after blood flow-restricted elastic band training in older women. Oncotarget 7. [Crossref]

26. Yasuda T, Fukumura K, Fukuda T, Uchida Y, Iida H (2014) Muscle size and arteria stiffness after blood flow-restricted low-intensity resistance training in older adults. Scand J Med Sci Sport 24: 799-806. [Crossref]

27. Shimizu R, Hotta K, Yamamoto S, Matsumoto T, Kamiya K, et al. (2016) Low-intensity resistance training with blood flow restriction improves vascular endothelial function and peripheral blood circulation in healthy elderly people. Eur J Appl Physiol 116: 749-57. [Crossref]

28. Zaleski AL, Taylor BA, Panza GA, Wu Y, Pescatello LS, et al. (2016) Coming of Age: Considerations in the Prescription of Exercise for Older Adults. Methodist Debakey Cardiovasc J 12: 98-104. [Crossref]

29. Proctor DN, Parker BA (2006) Vasodilation and vascular control in contracting muscle of the aging human. Microcirculation 13: 315-327. [Crossref]
30. Seals DR, Walker AE, Pierce GL, Lesniewski LA (2009) Habitual exercise and vascular ageing. J Physiol 587: 5541-5549. [Crossref]

31. Devan AE, Seals DR (2013) Vascular Health in the Ageing Athlete. Exp Physiol 97 305-310. [Crossref]

32. Figueroa A, Okamoto T, Jaime SJ, Fahs CA (2018) Impact of high- and low-intensity resistance training on arterial stiffness and blood pressure in adults across the lifespan?: a review. Pflugers Arch [Crossref]

33. Fahs CA, Rossow LM, Loenneke JP, Thiebaud RS, Kim D, et al. (2012) Effect of different types of lower body resistance training on arterial compliance and calf blood flow. Clin Physiol Funct Imaging 32: 45-51. [Crossref]

34. Fahs CA, Rossow LM, Seo DI, Loenneke JP, Sherk VD, et al. (2011) Effect of different types of resistance exercise on arterial compliance and calf blood flow. Eur J Appl Physiol 111:2969-75. [Crossref]

35. Loenneke JP, Wilson JM, Wilson GJ, Pujol TJ, Bemben MG (2011) Potential safety issues with blood flow restriction training. Scand J Med Sci Sports 21: 510-518. [Crossref]

36. Strijdom H, Friedrich SO, Hattingh S, Chamane N, Lochner A (2009) Hypoxia-induced regulation of nitric oxide synthase in cardiac endothelial cells and myocytes and the role of the PI3-K/PKB pathway. Mol Cell Biochem 321: 23-35. [Crossref]

37. Hood JD, Meininger CJ, Ahjg MZ (2001) Rapid Communication. Screening. 10271030.

38. Larkin KA, Macneil RG, Dirain M, Sandesara B, Manini TM, et al. (2012) Blood flow restriction enhances post-resistance exercise angiogenic gene expression. Med $\mathrm{Sci}$ Sports Exerc 44: 2077-2083. [Crossref]

39. Takano H, Morita T, Iida H, Asada K, Kato M, et al. (2005) Hemodynamic and hormonal responses to a short-term low-intensity resistance exercise with the reduction of muscle blood flow. Eur J Appl Physiol 95: 65-73. [Crossref]

40. Thum T, Tsikas D, Frölich JC, Borlak J (2003) Growth hormone induces eNOS expression and nitric oxide release in a cultured human endothelial cell line. FEBS Lett 555: 567-571. [Crossref]

41. Wickman A, Jonsdottir IH, Bergström G, Hedin L (2002) GH and IGF-I regulate the expression of endothelial nitric oxide synthase (eNOS) in cardiovascular tissues of hypophysectomized female rats. Eur J Endocrinol 147: 523-533. [Crossref]

42. Ross MD, Malone E, Florida-James G (2016) Vascular Ageing and Exercise: Focus on Cellular Reparative Processes. Oxid Med Cell Longev 16: 18-20.

43. Ozaki H, Yasuda T, Ogasawara R, Sakamaki-Sunaga M, Naito H, et al. (2013) Effects of high-intensity and blood flow-restricted low-intensity resistance training on carotid arterial compliance: Role of blood pressure during training sessions. Eur J Appl Physiol 113: 167-74. [Crossref]

44. Lenting PJ, Christophe OD (2019) von Willebrand factor biosynthesis, secretion, and clearance?: connecting the far ends. Blood 125: 2019-2029. [Crossref]

45. Loon JEVAN, Kavousi M, Leebeek FWG, et al. (2012) von Willebrand factor plasm levels, genetic variations and coronary heart disease in an older population. $J$ Thromb Haemost 1262-1269. [Crossref]

46. Mari D, Ogliari G, Castaldi D, et al. (2008) Immunity \& Ageing Hemostasis and ageing.

47. Yasuda T, Fukumura K, Tomaru T, Nakajima T (2016) Thigh muscle size and vascular function after blood flow-restricted elastic band training in older women. Oncotarget 7: 33595-33607. [Crossref]

48. Lida H, Nakajima T, Kurano M, Yasuda T, Sakamaki M, et al. (2011) Effects of walking with blood flow restriction on limb venous compliance in elderly subjects. Clin Physiol Funct Imaging 31: 472-476. [Crossref]

49. Ozaki H, Sakamaki M, Yasuda T, Fujita S, Ogasawara R, et al. (2011) Increases in thigh muscle volume and strength by walk training with leg blood flow reduction in older participants. J Gerontol A Biol Sci Med Sci 66: 257-263. [Crossref]

Copyright: (C)2019 Amorim S. This is an open-access article distributed under the terms of the Creative Commons Attribution License, which permits unrestricted use, distribution, and reproduction in any medium, provided the original author and source are credited. 